\title{
How to Strengthen Positive Organizational Behaviors Fostering Experiential Learning? The Case of Military Organizations
}

\section{Andrzej Lis*}

\begin{abstract}
The aim of the paper is to study the challenges concerning organizational behaviors crucial for Lessons Learned capabilities in military organizations as well as to indentify the solutions and recommendations to develop and strengthen positive organizational culture, climate and behaviors fostering experiential learning. The attention is focused around positive behaviors recognized by NATO as the key success factors for Lessons Learned capabilities such as: the engagement of leaders, positive mindset, willingness to share information and stakeholder involvement. The contents of the paper are mainly based on the interviews with Lessons Learned experts and practitioners representing both NATO commands, bodies and national Lessons Learned military organizations. Moreover, the outcomes of the analysis of selected military documents and the literature survey contributed to the study.

Keywords: organizational learning, Lessons Learned, positive organizational behaviors, leadership, information sharing, stakeholder involvement, positive mindset, military organizations.
\end{abstract}

\section{Introduction}

Positive Organizational Scholarship, which emerged a decade ago (cf. Cameron, Dutton and Quinn, 2003), nowadays is considered one of the most influential trends within the theory and practice of management. The positive organizational potential is recognized as the key determinant of positive organizational behaviors stimulating the development of an organization (cf. Stankiewicz, 2010; Peyrat-Guillard and GlińskaNeweś, 2010). The role of positive organizational culture, climate and behaviors is particularly important for the processes of managing organizational knowledge (cf. Kalińska, 2006, pp. 263-268; Glińska-Neweś, 2006, pp. 288-296; Glińska-Neweś, 2007, pp. 85-122). Due to its pivotal role for contemporary organizations, the topic attracts the attention of numerous researchers. Nevertheless, the majority of studies

Dr Andrzej Lis, Katedra Podstawowych Problemów Zarzqdzania, Wydział Nauk Ekonomicznych i Zarzqdzania, Uniwersytet Mikołaja Kopernika w Toruniu; Centrum Doktryn i Szkolenia Sił Zbrojnych w Bydgoszczy; andrzejlis@econ.umk.pl. 
gives the emphasis to business companies, while the public sector seems to be underrepresented. Therefore, the aim of this paper is to contribute to filling this gap and to study the process of developing positive organizational behaviors critical for Lessons Learned capabilities in military organizations.

The author's previous research findings on military Lessons Learned capabilities (Jabłoński and Lis, 2012b) and their key success factors "collected from the NATO, U.S. and Polish military Lessons Learned communities confirm the significant role played by positive organizational behaviors in experiential learning and organizational improvements implementation" (Lis, 2012). Positive attitudes, engagements and behaviors of commanders, Lessons Learned personnel and the rank-and-file members of the armed forces have been found to be the key success factors for Lessons Learned capabilities. The study has encompassed the perspective of the NATO Joint Analysis and Lessons Learned Centre (JALLC), the U.S. Centre for Army Lessons Learned (CALL) and the Polish Armed Forces Doctrine and Training Centre (PAF DTC). The key positive behaviors including: (1) commanders' guidance, engagement in learning processes, and promotion of organizational learning and knowledge exchange; and (2) the stakeholders' involvement expressed in capturing observations, sharing information and learning from others have been listed among the prerequisites for effective Lessons Learned systems.

As the outcome of the aforementioned exploration, the new research question has been identified: How to develop and strengthen positive organizational behaviors fostering Lessons Learned in military organizations (Lis 2012)? Finding the answer to this question is the main aim of the study. In comparison with previous surveys, the emphasis of the research attention is shifted to the process-oriented approach aimed at establishing intra-organizational conditions favorable for experiential learning and implementing improvements. In effect, the aforesaid problem becomes the main research question of the next stage of the scientific exploration and the following detailed research problems are identified (Lis 2012):

1. "What challenges (problems) concerning: the engagement of leaders, positive mindset, willingness to share information and stakeholder involvement are [...] faced by Lessons Learned communities in military organizations ?

2. What are [...] the solutions to these challenges (problems)? What has already been done? What are the best practices in this area? What can be done in the future?

3. What other organizational behaviors or the elements of organizational culture and climate are stimulants or obstacles to the Lessons Learned capability development?

4. Are there any observations, lessons and best practices on managing organizational behaviors which can be exchanged between military organizations and other business and non-profit sectors?"

The aforementioned research problems provide the guidance to achieve operational objectives of the study and determine its scope and field of interest. The 
paper is structured in accordance with the IMRD model. The introduction is followed by the description of applied research methods, techniques and tools. Then, the results of survey are presented and analyzed. The discussion of research findings concludes the paper.

\section{Method}

The toolbox applied to solve the aforementioned research problems consisted of the following methods: (1) interviews with Lessons Learned experts and practitioners, and (2) the analysis of military documentation. Moreover, in discussion, the findings from the primary sources were juxtaposed, compared and contrasted with secondary sources published both in military and civilian literature.

Interviews, conducted between July and September 2012, enabled the collection of the Lessons Learned practitioners' opinions and insights structured around the aforementioned research problems. The respondents represented both: NATO commands and bodies as well as national organizations responsible for Lessons Learned. Moreover, additional unstructured interviews on the role played by positive organizational behaviors in organizational learning in a military environment were conducted with Lessons Learned staff officers representing Central and East European nations. In total, seven Lessons Learned practitioners from six different organizations (including three international and three national organizations) contributed to the survey. Among the respondents, there were three active officers (ranks from major to colonel), three civilians (including one $\mathrm{PhD}$ ) and one retired officer. Apart from accomplishing Lessons Learned duties in their organizations, two of the respondents had an experience in conducting scientific surveys within the area of interest.

The analysis of military documentation supporting the empirical survey encompassed: doctrines, directives, manuals and handbooks. Due to the focus on the practical perspective, special attention was given to Lessons Learned manuals and handbooks implemented in NATO, the U.S. Army and the Polish Armed Forces.

\section{Research}

\section{Challenges}

The first objective of the study is to identify the challenges concerning organizational behaviors faced by military Lessons Learned communities. The attention is focused on behaviors recognized by the NATO Bi-Strategic Command Lessons Learned Directive (as quoted in NATO LL Handbook, 2011, p. 10) as the key success factors for Lessons Learned capabilities (cf. Lis, 2012): the engagement of leaders, positive mindset, willingness to share information and stakeholder involvement. The first step to achieve the objective is to categorize positive behaviors of leaders (commanders) and the rankand-file members of an organization. The catalogue of such behaviors is presented in Table 1. 
Table 1. Positive organizational behaviors for Lessons Learned - the checklist

\begin{tabular}{ll}
\hline \multicolumn{1}{c}{ Leadership } & \multicolumn{1}{c}{ Individuals (mindset) } \\
\hline $\begin{array}{l}\text { Leaders regularly remind staff of the importance } \\
\text { they place on LL }\end{array}$ & $\begin{array}{l}\text { Individuals actively seek out LL information } \\
\text { when they start a new task } \\
\text { Leaders reward staff for the sharing and use of } \\
\text { lessons in their work }\end{array}$ \\
$\begin{array}{l}\text { Leaders are accessible to make timely decisions } \\
\text { to share their lessons with others } \\
\text { Individuals feel safe and empowered to share } \\
\text { Leaders pay attention to the status of Remedial } \\
\text { and use lessons }\end{array}$ \\
$\begin{array}{ll}\text { Actions and prioritize resources to ensure it gets } \\
\text { completed }\end{array}$ \\
$\begin{array}{ll}\text { Leaders provide L[essons] L[earned] S[taff] } \\
\text { O[fficers] with the necessary support to develop } \\
\text { and monitor progress of L[essons] I[dentified] }\end{array}$ \\
\hline $\begin{array}{l}\text { Source: The NATO Lessons Learned Handbook (2011). Monsanto: Joint Analysis and Lessons } \\
\text { Learned Centre, p. E-1. }\end{array}$ \\
\hline
\end{tabular}

Both researchers and practitioners highlight the key role played by commanders in a Lessons Learned business. As observed by Lis (2012), due to the fact that "the Lessons Learned process combines experiential learning and continuous improvements, the will and decisions of military executives are necessary to put lessons identified and recommendations into practice". The commanders' engagement and support are crucial for the whole Lessons Learned process, but they are indispensable in the remedial actions phase. Leadership in a Lessons Learned process is expressed through guidance to establish priorities and allocate rare resources, commanders' engagement and their promotion of a Lessons Learned capability within and outside an organization (Hallet et al., 2009, p. 43).

While conducting an analysis of the challenges to managing positive organizational behaviors, it is required to distinguish between the actors responsible for Lessons Learned capabilities within their armed forces or NATO ("Lessons Learned systems' enablers") and other organizations ("the stakeholders of the Lessons Learned systems"). Within organizations accomplishing the function of Lessons Learned enablers, the promotion of knowledge management and organizational learning is one of their top priorities. Therefore, their leaders and personnel are usually highly motivated and show positive attitude to capturing observations, learning from experience, implementing improvements and sharing lessons. The respondents highlight the commanders' enthusiasm and their personal engagement in promoting Lessons Learned within NATO and their armed forces. They point out the variety of approaches to accomplish this task (direct promotion versus focus on sharing published products and showing their value).

As regards to military organizations other than Lesson Learned enablers, the respondents claim that commanders usually perceive the high priority of Lessons Learned. What is more, one of the respondents representing a Central European army observes that nowadays Lessons Learned issues are trendy. In his opinion, military 
leaders have, or at least officially declare, positive attitudes to developing Lessons Learned capabilities saying that "if it is new it must be good" and "if NATO has it we need to have it, too". Nevertheless, due to extreme time pressure, commanders deal first and foremost with urgent issues, not the most important ones. Therefore, sometimes commanding officers do not engage personally enough into Lessons Learned business delegating it entirely to staff personnel. In effect, experiential learning and change management aimed at continuous organizational improvement may not receive sufficient leadership engagement and support.

Regarding the rank-and-file members' engagement in the Lessons Learned process, the willingness to share information and to apply lessons and recommendations into daily business are identified as key challenges. As observed by one of the interviewed Lessons Learned practitioners: "a problem remains to convince the personnel to contribute to the changes in routine activities and processes which have been repeated in the same way for a long period of time and are not at all considered as best practices". Sharing information is another prerequisite for an efficient and effective organizational learning. Nevertheless, sometimes a strong resistance to sharing is observed. The NATO Lessons Learned Handbook (2011, p. 39) enumerates the following explanations for not sharing information provided by the military personnel:

- "Sharing negative experiences creates embarrassment and/or blame;

- It is not worth sharing until we have a solution;

- Sharing information is a risk: information obtained by the enemy could be used to exploit our weaknesses;

- Lessons can only be learned by doing: documenting experiences is a waste of time;

- The lessons are classified and we cannot change that to share them;

- Technical barriers hinder the free transfer of electronically stored information."

What is interesting, the problem of not sharing information is observed by the respondents representing both the armed forces having long experience in Lessons Learned (i.e. the U.S. Army) and the organizations where experiential learning is an up-to-date issue (i.e. the Polish Armed Forces). The resistance to share information and knowledge is particularly strong when the principles and rationale of Lessons Learned systems are in clash with the values and beliefs embedded in national and organizational cultures. Moreover, the hierarchical structure of military organizations may create an additional barrier blocking the flow of information and discouraging individuals' initiative and creativity. Therefore, in such a case the change of mental models is a prerequisite to develop a learning organization within a military context (cf. Jabłoński and Lis, 2012a, p. 22).

Misunderstanding of the role of experiential learning and Lessons Learned personnel by commanders and soldiers is another often problem, especially in the early stages of Lessons Learned programs. As experienced by the U.S. CALL, its "observers during (...) initial operations were often regarded by commanders in the field as inspectors sent to observe and document shortcomings and mistakes, and 
some resisted the attachment of CALL observers to their units for this reason" (Lackey, 2003, pp. 81-82). Such an opinion is confirmed by interviewees from other nations, too. Therefore, Lessons Learned staff officers are recommended to distinguish from any auditors or inspectors. Similarly, the difference between an analysis conducted within a Lesson Learned process and evaluation is highlighted in related documents (cf. Joint Analysis Handbook, 2007, pp. 5-7).

The balance between personnel rotation and the continuity of the organizational memory and routine is listed among challenges experienced by Lessons Learned communities in military organizations. From the perspective of knowledge management and organizational learning, the rotation on military positions (usually every three years) is perceived simultaneously as a threat endangering organizational memory and as an opportunity of bringing new, fresh ideas. Therefore, the mixed establishment including both military personnel and civilian employees is recommended. As highlighted by the JALLC on its website "balance between scientific expertise and operational experience provided by a mix of military (credibility), civilian (continuity) and contractor (flexibility) analysts is essential to ensuring high-quality, insightful JALLC products".

\section{Solutions}

The second objective of the study is to identify best practices and solutions implemented by military Lessons Learned communities in order to manage positive organizational behaviors in an efficient and effective way. With regard to enhancing the leaders' and organization members' engagement and their enthusiasm for Lesson Learned and organizational learning, the following recommendations are provided by the experts from the NATO Lessons Learned community: (1) showing practical value of Lessons Learned; (2) disseminating LL products to right recipients within an organization; and (3) providing key executives with summaries focused on the most crucial issues for their decisions. A similar point of view is shared by one of the respondents. In his opinion "the best way to gain commanders' support is to present a clear, simple and understandable plan of LL process implementation into organizational processes and procedures". Certainly, the key success factor is to ensure that the Lessons Learned business is perceived as "a valuable skill set" and not as "a bureaucratic burden" (cf. Sewell, 2009, pp. 35-37).

According to the NATO Lessons Learned Handbook (2011, p. 4) "[e]veryone in an organization has a responsibility for learning lessons, but the L[essons] L[earned] $\mathrm{S}$ [taff] O[fficer] is central to the organization's efforts to engage everybody in seeing the value of learning lessons. If people are not engaged, they see no value and do not actively participate. It then becomes impossible for learning to take place, nullifying the LL process. The simplest way to get everyone involved in learning lessons is to ensure that the LL capability is constantly demonstrating value. To do this, the LLSO has an important role to play in conducting staff work to support the organization's LL process, LL information sharing and participation in the LL community." Having in 
mind the aforementioned general rules, LL procedures and tools should be tailored to particular needs and situation of a given organization. For instance, an interesting and valuable set of recommendations aimed at managing Lessons Learned Critical Success Factors was developed in the NATO Joint Warfare Centre (cf. Table 2). The catalogue includes practical hints for Lessons Learned staff officers aimed at achieving leadership engagement, stakeholder involvement and information assurance in an efficient and effective way.

Table 2. Managing Lessons Learned Critical Success Factors - the lessons from the JWC

\begin{tabular}{lll}
\hline \multicolumn{1}{c}{ Leadership engagement } & \multicolumn{1}{c}{ Stakeholder involvement } & \multicolumn{1}{c}{ Information Assurance } \\
\hline $\begin{array}{l}\text { Inject LL discussions into Battle } \\
\text { Rhythm }\end{array}$ & $\begin{array}{l}\text { Engage contributors and } \\
\text { provide feedback } \\
\begin{array}{l}\text { Invite Chief of Staff Office to LL } \\
\text { Working Group } \\
\text { Prepare well-developed lessons } \\
\text { returns } \\
\text { Update contributors with } \\
\text { progress }\end{array}\end{array}$ & $\begin{array}{l}\text { Actively manage observations } \\
\text { Encourage originators to } \\
\text { analyse root causes } \\
\text { Exploit Subject Matter Experts }\end{array}$ \\
$\begin{array}{l}\text { Provide evidence of risk or } \\
\text { Exploit unit Tasker Tracker } \\
\text { systems }\end{array}$ & Actively manage databases \\
$\begin{array}{l}\text { Brief during exercise } \\
\text { preparation }\end{array}$ & Exploit lessons from outside & Exploit other LL archives \\
\hline $\begin{array}{l}\text { Source: Eden A., Sewell P. (2012), Making the Lessons Learned process work. The lecture delivered } \\
\text { at the LL Staff Officers Course, SWEDINT, Livgardet 27-31 August 2012. }\end{array}$ \\
\hline
\end{tabular}

The U.S. Center for Army Lessons Learned (CALL) enumerates three factors crucial for gaining acceptance for a Lessons Learned program in the U.S. Army: (1) introducing the After Action Review, (2) non-attributing lessons to specific units, and (3) showing value of lessons to the force. As pointed out by the CALL respondent, "the single-most important organizational behavior that fostered the acceptance of lessons learned across the Army was the After Action Review (AAR). This honest, 360-assessment got units, Soldiers and particularly leaders accustomed to listening to each other's experiences and appraisal of what actually occurred in operations and why things happened the way that they did. The AAR methodology sold this to commanders and leaders as a way to find this out with a far greater degree of accuracy and detail than they had previously enjoyed and then laid out a way ahead for them to use the information gathered to structure training to improve on shortfalls and sustain adequate or superior performance. Written AARs and the training feedback products (to training units) produced by the training cadre at the C[ombat] T[raining] C[enters] also formed the backbone of CALL's initial sources of information for its CTC products."

"The non-attribution of lessons to specific units (except for areas where positive performance was involved)", was listed as the second prerequisite in gaining acceptance for a Lessons Learned program. The CALL respondent admits that initially willingness to share information was a real challenge for organizational learning initiatives. 
Overcoming this resistance the organization "took a valuable lesson from that training environment, which held as one of its core beliefs the Las Vegas philosophy of "what happens here, stays here." In effect, while disseminating lessons across the U.S. Army, the CALL has avoided unveiling the identity of units and individuals unless the lessons were truly positive. Such an approach enabled the CALL to build-up "trust among units, leaders and Soldiers that the information (...) gathered from their operations would not be used against them or be used to paint them in an unfavorable light".

Showing value of the Lessons Learned capability to the force was listed as the third key factor to foster positive organizational behaviors favorable for experiential learning. Due to the fact that the Lessons Learned process combines organizational learning and change management, analyses and lessons identified are valuable only if they provide commanders with recommendations for remedial actions. As stated in the Allied Joint Doctrine for the Conduct of Operations (AJP-3B, 2011, p. 4-19) " $\mathrm{t}]$ he purpose of a Lessons Learned procedure is to learn efficiently from experience and to provide validated justifications for amending the existing way of doing things, in order to improve performance". Therefore, in order to buy-in the members of an organization, the Lessons Learned personnel "must be able to disseminate its information effectively so that its customers can use the information to improve". As observed by respondents "this dissemination can be via many means [such as]: websites, databases, hard-copy products, forums, etc. In fact, the use of multiple formats is probably best, since not everyone, for example, has computer access in the field, requiring the dissemination of lessons in hard copy". Recently, dissemination has received more and more attention of Lessons Learned practitioners. Its role is highlighted both within the daily work and official documents. For instance, in 2011, the dissemination stage was added to the generic model of the NATO Lesson Learned process.

\section{Change}

Changing values, beliefs and attitudes represented by the members of an organization in order to buy them into the idea of Lessons Learned, develop their positive mindset, and stimulate their involvement and willingness to share information is a real challenge for a Lessons Learned community. Such a point of view is shared by the majority of the respondents participating in the survey. As observed by one of them: "The most crucial lesson identified for the implementation of the LL system is the mindset change of the personnel. [Nevertheless] a generally applicable model to achieve the mindset change does not exist. Each organization requires a different approach". Changing positive organizational potential, culture and climate is a long and evolutionary process rather than a revolutionary turn-around. As highlighted by one of the interviewees "things take time". Therefore, incremental improvements seem to be a recommended way of implementing change. Simultaneously, Lessons Learned personnel should apply a product-oriented approach focusing their attention on showing value of Lessons Learned and providing high quality products. 
"Start small and build upon success" - this is the U.S. CALL's recommendation for managing positive organizational behaviors in the Lessons Learned context. As observed by the interviewee, "for CALL, this was almost pre-ordained, because in the mid-, to late-1980s, CALL, by necessity, focused on Combat Training Center (CTC) operations and the lessons there from. [The organization] disseminated directly to units and war fighters, which (...) also was a key ingredient. Leaders and Soldiers gradually grew confident that if they learned the lessons we published, they would perform better during their CTC rotation. When the Army started getting more routinely involved in contingency operations following Operation Just Cause in Panama, CALL started publishing lessons learned from those as well. For Operation Desert Shield, CALL produced a handbook on conditions in the theater as well as what could be expected from their Iraqi opponents and it was a huge hit with troops. (...) The longer-term operations, such as Haiti, Somalia, Bosnia and Kosovo, allowed CALL to build on credibility with Soldiers and leaders because the lessons we were harvesting and publishing had a direct impact on their operational success and in saving lives". As admitted by the CALL, buying troops into a U.S. Army Lessons Learned program had been a long process lasting over the 1980s and 1990s (cf. Lackey, 2003, pp. 79-83).

The CALL's way to get the acceptance of U.S. Army commanders and soldiers and to buy them into a Lessons Learned business provides an example of the evolutionary, incremental change of mindset. The case shows how positive behaviors and attitudes to experiential learning have been shaped along with the development of the U.S. Army Lessons Learned capability. This is one of the advantages experienced by the first movers. The followers, such as other military organizations responsible for buildingup national Lessons Learned systems in their armed forces, face other challenges. On one hand, they may benefit from lessons learned from pioneers, but on the other one their sponsors and stakeholders expect immediate deliverables of high added value. Paradoxically, meeting these requirements is extremely difficult without positive organizational culture, climate and behaviors for organizational learning. Changing mindset is a time consuming activity. In effect, the risk of vicious circle becomes relatively high.

The resistance from the members of an organization is another challenge which needs to be taken into account while planning and implementing any change. Overcoming this resistance may be extremely important and difficult while undertaking the effort to change organizational culture, climate and behaviors. The lessons from the U.S. Army prove that the After Action Review process is a strong force driving the positive change into organizational behaviors favorable for Knowledge Management and experiential learning. Nevertheless, the implementation of the AAR may be a real challenge, too. One of the interviewees, during his tour in Afghanistan as a Polish Armed Forces battalion commander, had attempted to inculcate the AAR process into his subordinates. His idea was to improve the operations of the battalion and to foster the cooperation with troops attached to the battalion from other units. He admits that he faced strong resistance from company and platoon commanding officers while 
the leaders of attached units generally presented positive attitudes to his initiative. What was astounding, among the opponents there was one of the officers who had been trained in the U.S. where the AAR is deeply embedded into the organizational culture of the Armed Forces. The personnel perceived the open dialogue on their mistakes as the face threatening act and the AAR as an additional bureaucratic and time-consuming procedure. Although the AAR was aimed at discussing problems and finding solutions and improvements, initially the participants shifted their attention to blaming each other. Then, situation improved and finally the AAR provided constructive outcomes. At the beginning, AAR sessions were organized and chaired by the battalion commander and his deputy. In the second step, the leaders handed over the responsibility to company commanders. Nevertheless, when left without battalion command supervision, the "quality" of the AAR weakened. In spite of the challenges while managing the "AAR experiment" in his battalion, the respondent is convinced of the value of this technique for Lessons Learned processes. He highlights the urgency to train all the personnel in the AAR procedure and to show them the benefits of applying it in daily routine.

Summing up the aforementioned case study, the cultural differences between nations and organizations should be highlighted. While by some nations, the selfevaluation session is considered "a positive feedback", by others it may be perceived as "the acknowledging the failure" (cf. Trompenaars and Hampden-Turner 2002, p. 34 as cited in Miroński 2010, p. 53). Similarly, referring to the military context, Scheider (2011, p. 13) identifies the ignorance of national culture among misunderstandings and obstacles in developing and delivering After Action Review. He claims that "[i] $\mathrm{n}$ some national cultures and in many na-tions' military cultures, self-critique is very difficult, as is expressing opinions that may contradict those of the leader or facilitator". Nevertheless, the change of organizational culture and attitudes to Lessons Learned initiatives is possible. As highlighted by the CALL, "some armies have successfully overcome this cultural difference after working with the U.S. military and understanding the importance of learning from their past" (Establishing..., 2011, p. 4). Moreover, another important lesson can be derived from the story: A successful implementation of the Lessons Learned initiative requires both leadership engagement and positive attitudes of all the personnel combined in order to overcome the psychological barriers and to appreciate the value of new solutions.

\section{Discussion}

Research findings prove the crucial role played by positive organizational behaviors in developing Lessons Learned capabilities in military organizations. First and foremost, leaders and all the members of an organization contribute to the success of failure of a Lessons Learned business. Therefore, there has been identified the need to study "How to develop and strengthen positive organizational behaviors fostering Lessons Learned in military organizations?" Finding the answer to this question has been the main aim of the study. The aim has been achieved in three steps. First of all, the challenges concerning positive organizational behaviors faced by Lessons Learned communities in military 
organizations have been identified. Secondly, possible solutions to these challenges have been considered. Finally, managing the change of organizational behaviors has been discussed.

Analyzing the challenges to developing and strengthening positive organizational behaviors crucial for Lessons Learned processes in military organizations, the distinction should be made between issues concerning leadership and personnel involvement. As regards to leadership-related challenges, time shortfalls and the right prioritization seem to be the key points. Efficient and effective Lessons Learned processes require the commanders' guidance to establish priorities and allocate rare resources, their engagement and promotion of a Lessons Learned capability. Nevertheless, due to time pressure there is a risk that commanders deal first and foremost with urgent issues, not the most important ones. Information sharing and the personnel rotation are listed among the challenges for engaging all the troops within Lessons Learned business. The catalogue of barriers to effective sharing information has been identified. Nevertheless, taking into account the cultural determinants of intra-organizational communication (cf. Glińska-Neweś, 2007, pp. 205-207), information sharing seems to be especially challenging in military organizations due to their hierarchical structures (cf. Jabłoński and Lis, 2012a, p. 22). As regards to the impact which personnel rotation has on Lessons Learned processes, there is some ambiguity. Both opportunities of bringing new, fresh ideas and threats to organizational memory need to be taken into account. Misunderstanding of the role of Lessons Learned personnel by both commanders and file-and-rank soldiers is another problem. A serious risk of perceiving Lessons Learned staff officers as "inspectors" or even "spies" conducting assessment and evaluation not as "allies" collecting observations in order to provide assistance to the troops may have a detrimental effect to a Lessons Learned capability.

The opinions and insights of interviewed experts and Lessons Learned practitioners enable to enumerate some solutions to the problems identified above. Showing value seems to be the key point recommendation for developing and strengthening positive organizational behaviors crucial for Lessons Learned capabilities. Lessons Learned systems combine the processes of managing knowledge and change. They have a very practical rationale. "The idea of Lessons Learned in an organization is that through a formal approach to learning, individuals and the organization can reduce the risk of repeating mistakes and increase the chance that successes are repeated. In the military context, this means reduced operational risk, increased cost efficiency, and improved operational effectiveness" (NATO LL Handbook, 2011, p. 1). Therefore, Lessons Learned business needs to be product-oriented. Gaining commanders' and troops' respect by the U.S. CALL through providing high quality products customized to their needs confirms such an approach. Similarly as in a business sector, the "customers" analyze costs and effects seeking the highest value from their perspective. That is why it is important to develop and promote Lessons Learned capability as "a valuable skill set" enabling both leaders and the rank-and-file soldiers to achieve their aims and not as "a bureaucratic burden" which requires additional work but provides no value. 
Establishing clear ground rules while capturing observations and conducting analyses and providing soldiers with simple but effective tools and techniques supporting experiential learning are another lessons identified. As experienced by the CALL, non-attributing lessons to specific units enabled the organization to gain the acceptance for a Lessons Learned program within the U.S. Army ranks. Clear ground rules between Lessons Learned staff officers and their informants are the prerequisite for the mutual trust and communication, and in effect for capturing valuable observations and collecting data necessary to further analyses. Lessons Learned solutions combine a scientific approach, formal procedures and IT technology. Certainly, these elements are important for complex and multidimensional analyses and remedial actions undertaken at the strategic level. Nevertheless, in order to be effective the Lessons Learned business requires the engagement of all soldiers. Therefore, providing them with simple but effective tools and techniques supporting experiential learning is so crucial. The U.S. After Action Review may be listed as an example of such an instrument.

Managing the change of organizational behaviors crucial from the perspective of Lessons Learned has been the last, but not least, issue under the study. Although a generally applicable model to achieve the mindset change has not been identified, some principles have been observed. First and foremost, it should be stressed that each organization needs to develop its own way of changing mindset of its personnel. A situational approach should be adopted rather than a universal one. Secondly, mindset change is a long, evolutionary process. "Starting small and building upon success" is a good practice learned from the U.S. CALL. Thirdly, the impact of national and organizational culture must be taken into account while introducing changes. Finally, leadership engagement and zeal are the key factors in overcoming resistance to change. The role of leadership, highly appreciated in all types of organizations, seems to be particularly crucial in a military context.

Summing up, the study has identified the challenges concerning positive organizational behaviors faced by Lessons Learned communities in military organizations, possible solutions and good practices as well as some principles of managing the change of organizational behaviors. Due to the great importance of the topic both for the theory of knowledge management and the practice of managing Lessons Learned capabilities in military organizations, further scientific exploration of the research area is recommended, including both quantitative and qualitative studies.

\section{References}

AJP-3(B) Allied Joint Doctrine for the Conduct of Operations (2011). Brussels: NATO Standardization Agency.

Cameron, K.S., Dutton, J.E., Quinn, R.E. (Eds.). (2003). Positive Organizational Scholarship:

Foundations of a New Discipline. San Francisco: Berett-Koehler Publishers.

Establishing a Lessons Learned Program: Observations, Insights and Lessons (2011). Fort Leavenworth: Center for Army Lessons Learned. 
Glińska-Neweś, A. (2006). Kultura organizacyjna a procesy zarządzania wiedzą w polskich przedsiębiorstwach. In: M.J. Stankiewicz (Ed.), Zarzqdzanie wiedzq jako kluczowy czynnik międzynarodowej konkurencyjności przedsiębiorstwa (pp. 269-306). Toruń: Dom Organizatora TNOiK.

Glińska-Neweś, A. (2007). Kulturowe uwarunkowania zarzqdzania wiedzq w przedsiębiorstwie. Toruń: Dom Organizatora TNOiK.

Hallet, M. (2010). Leadership: The guiding force. The Three Swords Magazine, 17, $23-26$. Hallet, M., Mota, M., Pinot, J.H., Smack, M., Soegaard, P. (2009). Introduction to the NATO Lessons Learned capability. The Three Swords Magazine, 16, 38-45.

Instrukcja Systemu Wykorzystania Doświadczeń w Siłach Zbrojnych RP (2011). Bydgoszcz: Centrum Doktryn i Szkolenia Sił Zbrojnych.

Jabłoński, J., Lis, A. (2012a). Identyfikacja obserwacji w procesie wykorzystania doświadczeń. Przegląd Wojsk Lq̨owych, 59(2), 14-22.

Jabłoński, J., Lis, A. (2012b). Lessons Learned system as a tool of managing organizational knowledge: The case of military organizations. In: A. Nalepka, A. Ujwary-Gil (Eds.), Business and non-profit organizations facing increased competition and growing customers' demands. Nowy Sącz: Wyższa Szkoła Biznesu - National Louis University (submitted for publication).

Joint Analysis Handbook (2007). Monsanto: Joint Analysis and Lessons Learned Centre. Kalińska, M. (2006). Uwarunkowania wewnątrzorganizacyjne zarządzania wiedzą w polskich przedsiębiorstwach. In: M.J. Stankiewicz (Ed.), Zarzqdzanie wiedzq jako kluczowy czynnik międzynarodowej konkurencyjności przedsiębiorstwa (pp. 233268). Toruń: Dom Organizatora TNOiK.

Lackey, S. W. (2003). Spreading the Gospel of Lessons Learned: From the PfP Lessons Learned Working Group to Advanced Distributed Learning. Connections: The Quarterly Journal, 2, 79-90.

Lis, A. (2012). Positive organizational behaviors as the key success factors for Lessons Learned systems: The case of military organizations. Journal of Positive Management, 3(1) (submitted for publication).

Miroński, J. (2010). Zarządzanie wiedzą międzykulturową. E mentor, 35 (3), 51-58.

Peyrat-Guillard, D., Glińska-Neweś, A. (2010). Positive Organizational Potential, Organizational Commitment and Organizational Citizenship Behavior: A French/ Polish comparison. Journal of Positive Management, 1(1), 47-64.

Scheider, R. (2011). The After Action Review. The Three Swords Magazine, 19, 12-14.

Sewell P. (2009). Lessons Learned: A bureaucratic burden or a valuable skill set. The Three Swords Magazine, 16, 35-37.

Stankiewicz, M.J. (Ed.) (2010). Pozytywny Potencjał Organizacji: Wstęp do użytecznej teorii zarzq̨dzania. Toruń: Dom Organizatora TNOiK.

The NATO Lessons Learned Handbook (2011). Monsanto: Joint Analysis and Lessons Learned Centre.

Trompenaars, F., Hampden-Turner, Ch. (2002). Siedem wymiarów kultury. Kraków: Oficyna Ekonomiczna. 


\begin{abstract}
Polish)
Celem artykułu jest wskazanie wyzwań w zakresie kształtowania pozytywnych zachowań organizacyjnych kluczowych z perspektywy wojskowych systemów wykorzystania doświadczeń (Lessons Learned) oraz zidentyfikowanie rozwiqzań i rekomendacji służqcych umacnianiu pozytywnej kultury organizacyjnej, klimatu i zachowań sprzyjajqcych organizacyjnemu uczeniu się w oparciu o wykorzystanie doświadczeń. Uwaga badawcza została skoncentrowana na pozytywnych zachowaniach organizacyjnych uznawanych w NATO za kluczowe czynniki sukcesu systemów wykorzystania doświadczeń, takich jak: zaangażowanie dowódców i pozostałych członków organizacji, pozytywna mentalność oraz skłonność do dzielenia się informacjami. Zasadniczq metoda pozyskiwania danych zastosowanq $w$ procesie badawczym były wywiady $z$ ekspertami i praktykami reprezentujqcymi dowództwa i instytucje NATO oraz organizacje wojskowe odpowiedzialne za rozwój narodowych zdolności w zakresie wykorzystania doświadczeń. Ponadto, wykorzystano wyniki analizy wybranych dokumentów wojskowych oraz literatury przedmiotu.

Słowa kluczowe: organizacyjne uczenie się, wykorzystanie doświadczeń, pozytywne zachowania organizacyjne, przywództwo, wymiana informacji, organizacje wojskowe.
\end{abstract}

